\title{
Lake water stage dynamics in the Łęczna-Włodawa Lake District in 1991-2010
}

\author{
Zdzisław Michalczyk, Stanisław Chmiel, Marek Turczyński \\ Department of Hydrology, Faculty of Earth Sciences and Spatial Management, Maria Curie-Skłodowska University (UMCS), \\ Kraśnicka 2cd, 20-718 Lublin, Poland; e-mail: zdzislaw.michalczyk@umcs.lublin.pl
}

\begin{abstract}
In the years 1991-2010 the water stages of 38 lakes in the Łęczna-Włodawa Lake District were observed. Water stage dynamics of the Łęczna-Włodawa lakes was varied. A multi-annual trend with seasonal water stage variability was clearly observable. Low water stages were observed in the years 1994-1996 and 2004-2005, whereas the highest water stages were reported for 2002 and 2010 . The water stages of Lake Piaseczno, the deepest lake, were consistent with solar activity changes. Land improvement works in the Łęczna-Włodawa Lake District and black coal mining caused further local changes in the directions of flow of surface and underground water, as well as modifying the water stage regime of some of the lakes.
\end{abstract}

Key words: water stages, lake water dynamics, human impact

\section{Introduction}

Observations of lake water stages are used in hydrologic research and are scientifically and economically significant. The amount and dynamics of water resources retained in lake basins can be determined based on such observations. The aim of this paper is to analyse the changes in the water stages of the lakes in the Łęczna-Włodawa Lake District. This paper is based on field observations conducted over a 20-year period in the years 1991-2010, and in the case of Lake Piaseczno in the years 1971-2010.

The Łęczna-Włodawa Lake District is a subregion of Lublin Polesie and is situated at the westernmost end of the vast Polesie Lowland. Within the Lake District area there are 67 lakes (Wilgat et al. 1991), 61 of which have retained their natural character, whereas 6 have been converted into storage reservoirs. These are lakes of different origin, small in area (the biggest one having an area of $284 \mathrm{ha}$ ) and quite shallow. Only 7 lakes are more than 15 metres deep at the deepest point. Most of the lakes are becoming profusely overgrown and their original basins are becoming filled to a large extent with gyttja and peat, which indicates that they are in an advanced stage of disappearance. The lakes represent different trophic, thermal and hydrochemical types (Wilgat 1954; Wilgat et al. 1991; Harasimiuk et al. 1998).

Information on water stage changes in historical periods is reconstructed based on the analysis of lake basin areas, chronicles or cartographic materials. The first systematic observations of water stages were carried out in Lake Perespilno in 1957-1967 for the Forest Research Institute. The water stages of two lakes, Piaseczno and Białe Włodawskie, were registered from $1 \mathrm{Au}-$ gust 1971 to July 1982 using the hydrometric network of the present Institute of Meteorology and Water Management. In the following years, water stage readings were obtained continuously or periodically for Lake Piaseczno as part of the research done by the Department of Hydrology, UMCS, Lublin. In the years 19901992 such research was also conducted in a number of lakes by the Bogdanka Coal Mine. 


\section{Scope of research}

In early 1991, in collaboration with the Department of Hydrology UMCS, and the Bogdanka Coal Mine, gauges were installed in 12 lakes: Uścimowskie, Rogóźno, Brzeziczno, Piaseczno, Nadrybie, Bikcze, Uściwierz, Rotcze, Sumin, Zagłębocze, Łukie and Głębokie Cycowskie. In the same year gauge observations also commenced in 4 lakes of Polesie National Park and were carried out at one-week or one-month intervals. In 1993, in cooperation with Chełm Landscape Parks, water stage observations were commenced in the lakes of the eastern part of the ŁęcznaWłodawa Lake District. Observations of 29 lakes were carried out on the basis of monthly readings taken at the end of the first ten days of each month. On the whole, in the years 1991-2010, water stages were systematically or periodically registered for 38 lakes (Table 1), i.e. for $57 \%$ of the lakes in the Łęczna-Włodawa Lake District (Fig. 1). The collected data are not homogeneous and mostly come from several-year measuring series. However, the measurements altogether provide data for the evaluation of seasonal and annual water stage dynamics.
The summary of measurement periods and amplitudes of lake water stage variations for the years 1991-2010 as well as for 4 lakes subjected to a longer measurement series is presented in Table 1. Continuity of gauge readings was maintained for two entire decades (1991-2010) for 7 lakes (Fig. 1, Table 2) located in the vicinity of a mining field and for the Uściwierz lakes situated a little farther, i.e. Zagłębocze and Głębokie Cycowskie.

\section{Analysis of water stage changes}

Piaseczno is considered to be a benchmark lake with the longest observation period. It belongs to the group of lakes without flow whose stages were not disrupted by river waters or the waters flowing in from the Wieprz-Krzna Canal. In the years 1972-1981, the water stages of Lake Piaseczno followed, with a certain delay, the response of shallow underground waters to atmospheric inflow. After the seasonal maximum water stages in the years 1981-1982, there was a general downward trend until the summer months of 1997 (Fig. 2).

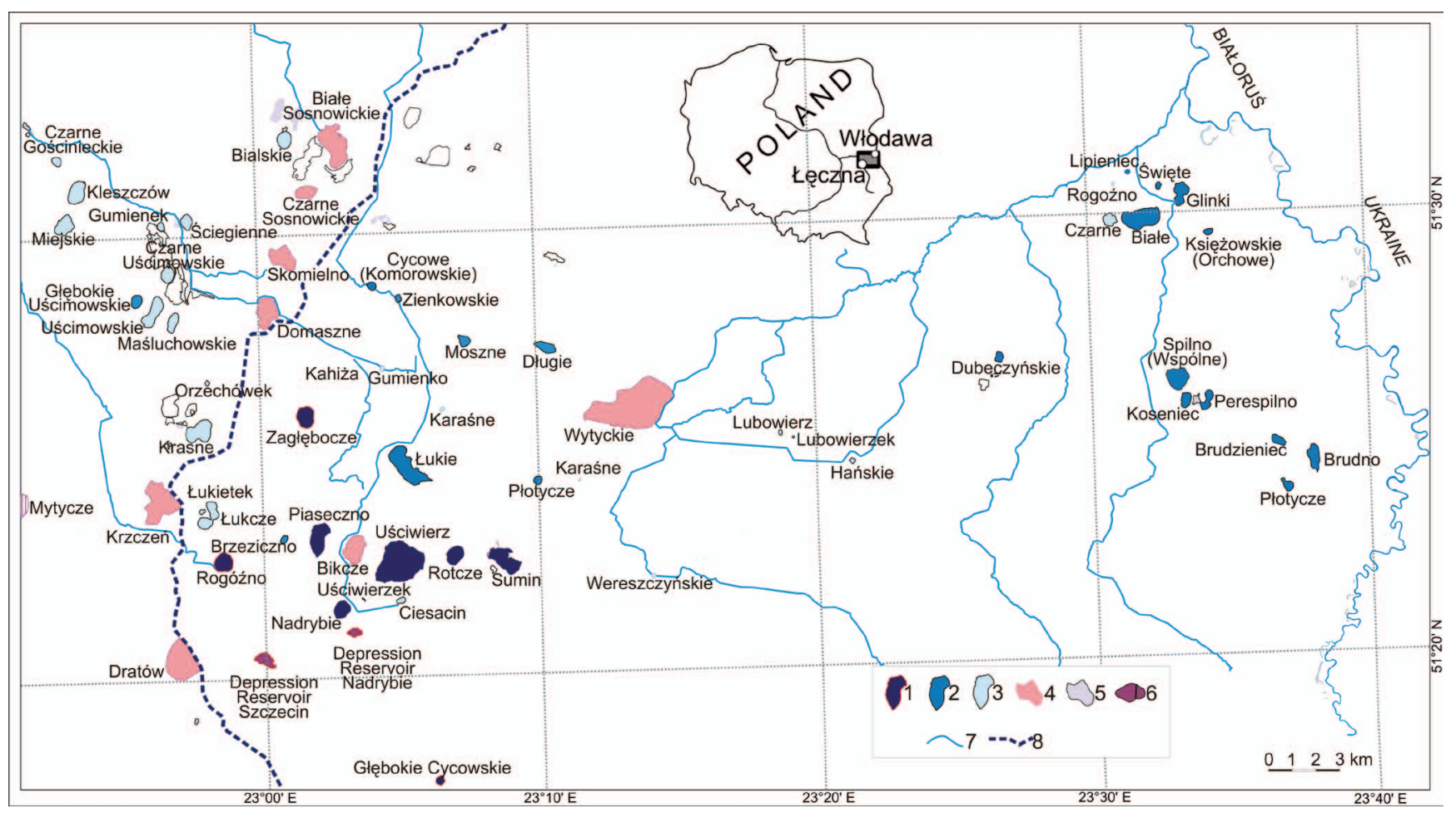

Fig. 1.Distribution of lakes in the Łęczna-Włodawa Lake District. 1 - lakes with water stages monitored in the years 1991-2010,2 - lakes with shorter water stage registration periods, 3 - other lakes, 4 - retention reservoirs, 5 - pond complexes, 6 - depression reservoir, 7 - main rivers, 8 - Wieprz-Krzna Canal 
Table 1. Observation periods and amplitudes of lake water stage variations $(\mathrm{cm})$

\begin{tabular}{|c|c|c|c|c|c|}
\hline Lake & Observation period & $\begin{array}{l}\text { Amplitude } \\
\text { [cm] }\end{array}$ & Lake & Observation period & $\begin{array}{l}\text { Amplitude } \\
\text { [cm] }\end{array}$ \\
\hline \multirow[b]{2}{*}{ Białe Włodawskie } & $1993-2004$ & 79 & \multirow[b]{2}{*}{ Łukie } & \multirow[b]{2}{*}{$1991-2005$} & \multirow[b]{2}{*}{70} \\
\hline & $\begin{array}{l}1971-1982 \\
1993-2004\end{array}$ & 79 & & & \\
\hline Bikcze & 1991-1996 & 54 & Moszne & $1991-2003$ & 51 \\
\hline Brudno & $1993-2004$ & 71 & Nadrybie & $1991-2002$ & 97 \\
\hline \multirow[b]{2}{*}{ Brudzieniec } & \multirow[b]{2}{*}{$1993-2004$} & \multirow[b]{2}{*}{78} & \multirow[b]{2}{*}{ Perespilno } & $1993-2002$ & 85 \\
\hline & & & & $\begin{array}{l}1957-1967 \\
1993-2002\end{array}$ & 85 \\
\hline \multirow{2}{*}{ Brzeziczno } & \multirow{2}{*}{$1991-1995$} & \multirow{2}{*}{40} & \multirow{2}{*}{ Piaseczno } & $1991-2010$ & 114 \\
\hline & & & & $1971-2010$ & 171 \\
\hline Ciesacin & $1993-2002$ & 71 & Płotycze & $1993-2004$ & 112 \\
\hline Cycowe (Komorowskie) & $1993-2003$ & 105 & Płotycze k.Urszulina & $1993-2003$ & 60 \\
\hline Czarne Sosnowickie & $1993-2003$ & 71 & Rogóźno & $1991-2010$ & 64 \\
\hline Długie & $1991-2003$ & 64 & Rotcze & $1991-2010$ & 92 \\
\hline Domaszne & 1993-2002 & 168 & Skomielno & 1993-2002 & 77 \\
\hline Dubeczyńskie & 1993-2002 & 85 & Słone & $1993-2002$ & 54 \\
\hline Glinki & 1993-2002 & 54 & Spilno (Wspólne) & $1993-2003$ & 108 \\
\hline Głębokie Cycowskie & $1991-2010$ & 54 & Sumin & $1991-2010$ & 104 \\
\hline Głębokie Uścimowskie & $1991-2002$ & 73 & Świerszczów & 1993-1999 & 87 \\
\hline Gumienko & $1991-2003$ & 45 & Święte & 1993-2002 & 58 \\
\hline Karaśne PPN & 1991-1998 & 43 & Uściwierz & $1991-2010$ & 75 \\
\hline Koseniec & 1993-2004 & 52 & Wytyckie & 1993-2002 & 89 \\
\hline Księżowskie (Orchowe) & $1993-2004$ & 64 & Zagłębocze & $1991-2010$ & 90 \\
\hline Lipieniec & 1993-2004 & 68 & Zienkowskie & $1993-2002$ & 109 \\
\hline
\end{tabular}

Table 2. Morphometric characteristics of selected lakes and their catchments

\begin{tabular}{|c|c|c|c|c|c|c|c|c|c|c|c|c|c|}
\hline Lake & 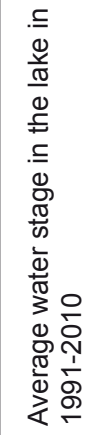 & 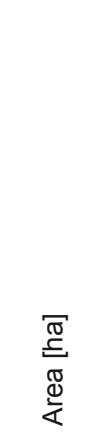 & 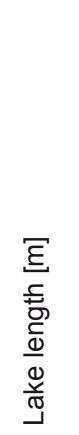 & 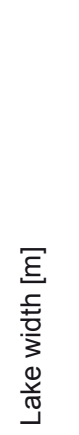 & 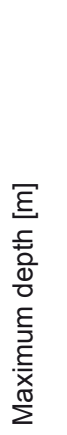 & 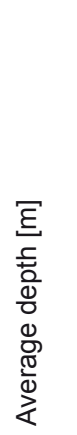 & 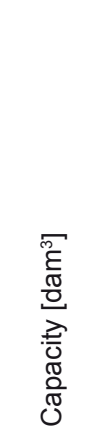 & 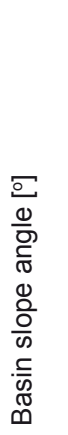 & 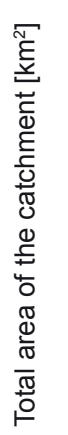 & 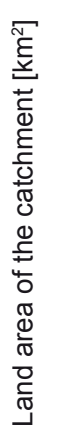 & 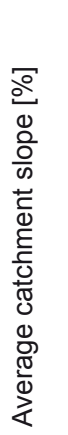 & 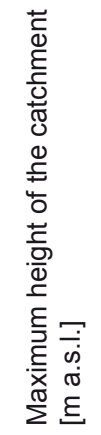 & 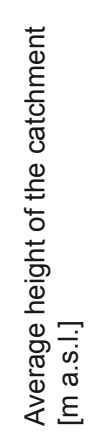 \\
\hline Głębokie Cycowskie & 171.95 & 11.40 & 410 & 350 & 5.70 & 3.70 & 438 & 2.45 & & & & & \\
\hline Piaseczno & 169.49 & 75.74 & 1413 & 762 & 39.4 & 10.7 & 8128 & 5.33 & 3.12 & 2.36 & 0.60 & 175.98 & 171.69 \\
\hline Rogóźno & 167.05 & 51.10 & 866 & 798 & 24.6 & 7.0 & 3571 & 3.63 & 8.14 & 7.63 & 0.51 & 176.25 & 171.03 \\
\hline Rotcze & 170.16 & 46.00 & 901 & 654 & 3.1 & 1.3 & 580 & 0.71 & 2.41 & 1.95 & 0.66 & 174.22 & 171.21 \\
\hline Sumin & 170.35 & 107.48 & 1590 & 915 & 5.5 & 1.5 & 1575.8 & 0.65 & 3.35 & 2.27 & 0.67 & 175.67 & 171.13 \\
\hline Uściwierz & 169.49 & 267.27 & 2337 & 1754 & 5.3 & 1.9 & 5177.4 & 0.63 & 5.26 & 2.59 & 0.39 & 173.95 & 170.10 \\
\hline Zagłębocze & 166.44 & 51.03 & 895 & 781 & 22.4 & 6.6 & 3357.1 & 3.62 & 4.21 & 3.71 & 1.17 & 174.20 & 168.71 \\
\hline
\end{tabular}




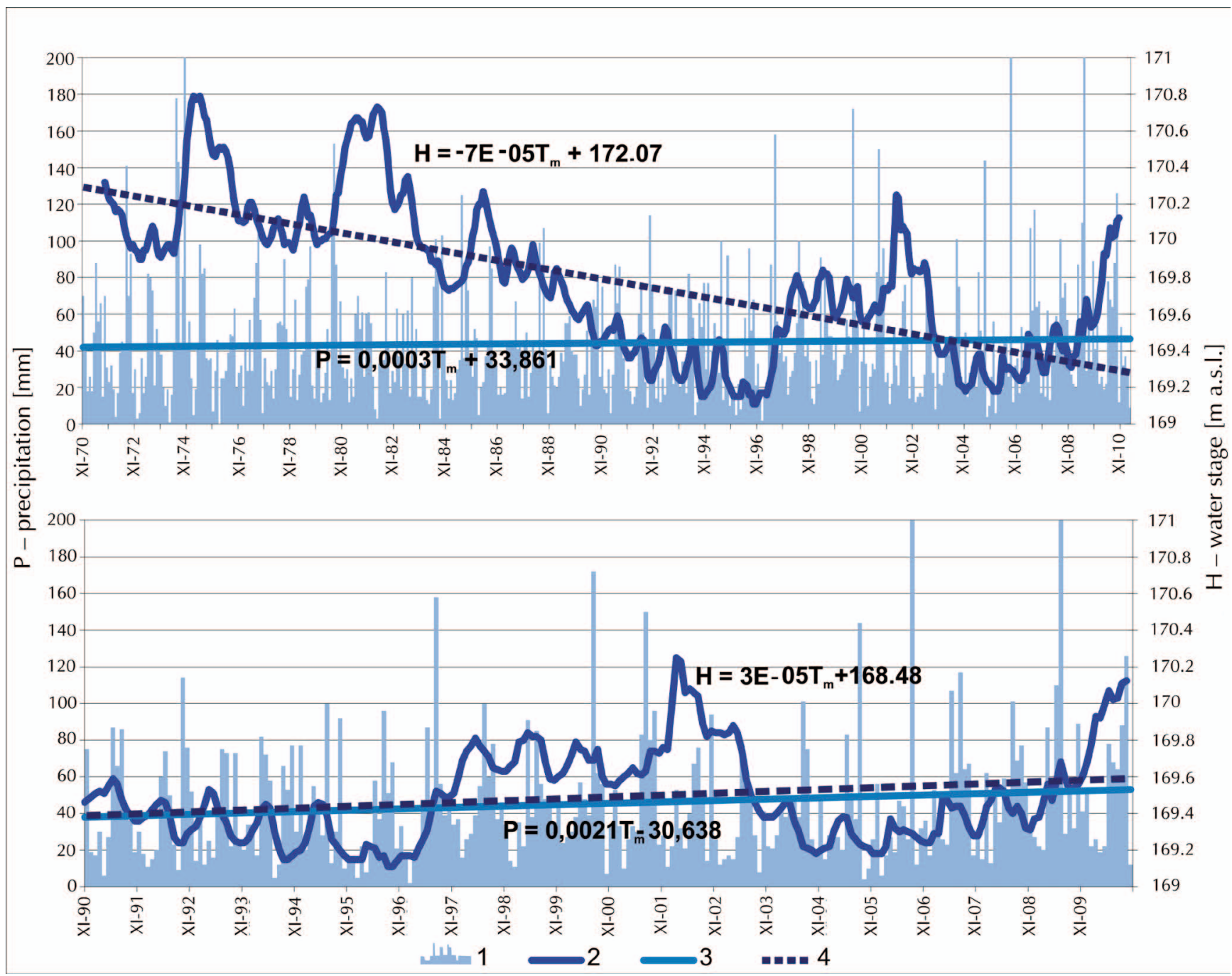

Fig. 2. Monthly precipitation totals (1) and water stages in Lake Piaseczno (2) for two observation periods A - 1970-2010, B - 1990-2010 and the trends: 3 - precipitation, 4 - lake

A particularly noticeable water stage drop was registered in the period 1983-1996 (Fig. 2). In 19941997 the water stages stabilised at a very low level. A sharp rise in the water stages, which began in 1997, was caused by heavy rainfall in the second half of 1997. In the following years the water stages rose until 2002. Low water levels were registered again in 20042007. In the last two years a high rise in water stages was recorded, which indicated that water resources in the region had been naturally replenished. In the years 1972-2010 the amplitude of water stage variation for Lake Piaseczno was $171 \mathrm{~cm}$, and for the twenty years of 1991-2010 it was $114 \mathrm{~cm}$. Lake Piaseczno shows an annual pattern of water stage changes, accompanied by seasonal changes, which is evidence that the winter-spring period plays an important role in the formation of water resources. A similar pattern of changes was observed for the neighbouring lakes, i.e. Uściwierz, Nadrybie, Rotcze and Sumin (Fig. 3).

Very low water stages were observed for all the lakes in the years 1994-1996 and 2004-2005. The highest lake water stages in the period of twenty years (1991-2010) were recorded in 2002 and 2010. In Lake Piaseczno, though, they did not reach the water level altitudes of the especially wet period of 1974-1982 (Fig. 2). Water stage changes result in the alteration of the area, depth and retention capacity of the lakes. For example, in the years 1991-2010, Lake Piaseczno's area increased from 64.2 to $71.3 \mathrm{ha}$, and its water capacity rose from 7.4 to $8.1 \mathrm{hm}^{3}$.

The amplitudes of water stage variations in all the monitored lakes, summarised for different time 


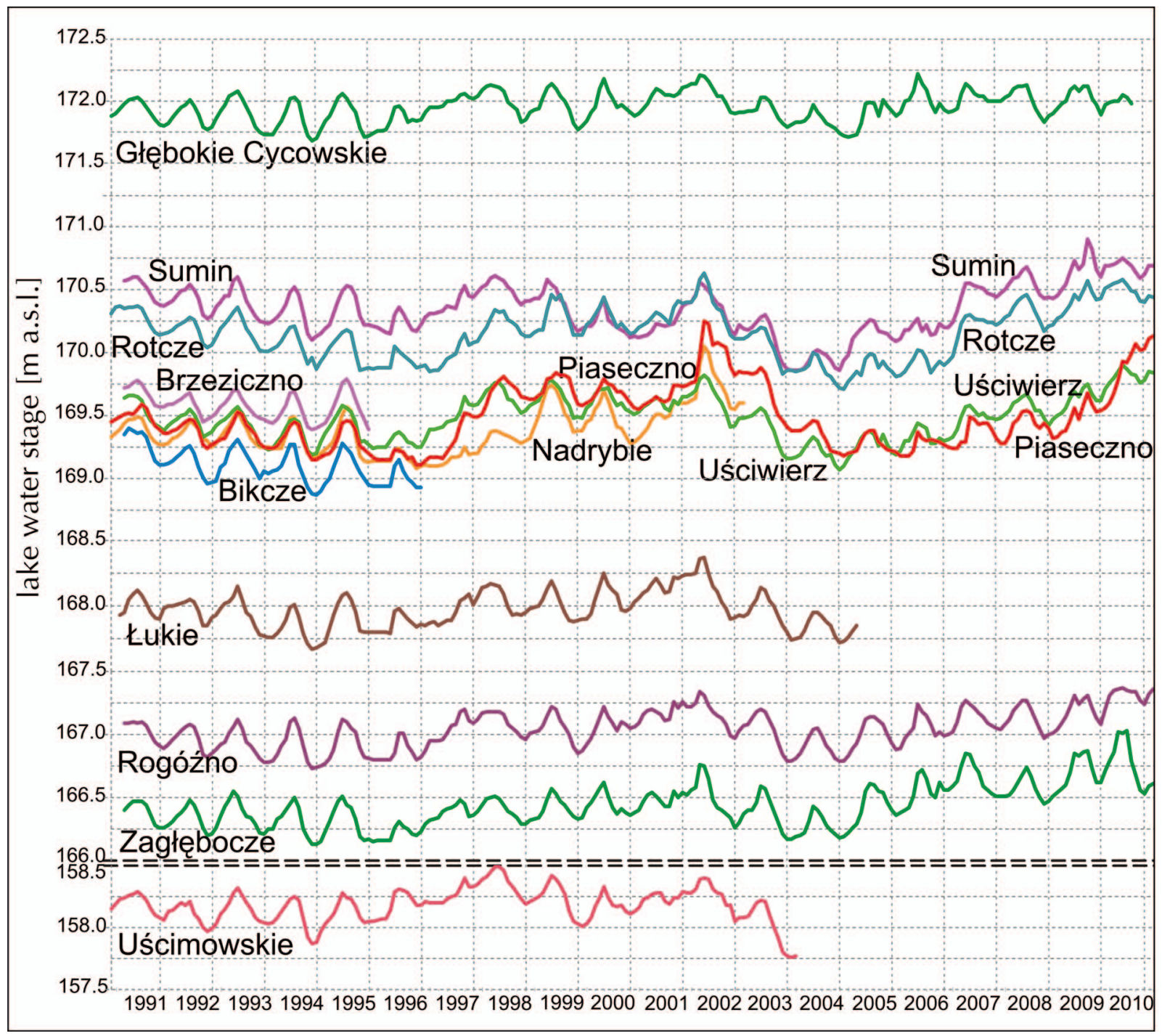

Fig. 3. Water stage changes in selected Łęczna-Włodawa lakes in 1991-2010

periods, vary significantly: from 43 to $171 \mathrm{~cm}$. In natural lakes which were not modified by human intervention the water stage fluctuations do not exceed 1 $\mathrm{m}$. The greatest water stage changes are caused by the interplay of different factors: inflow or outflow regulation, land amelioration, land drainage and water withdrawal for economic purposes.

The dynamics and fluctuation range of water stages in the lakes were modified to a certain degree within the area of ameliorated lands and nearby coal mines (Wilgat et al. 1997). In the south-western part of the Lake District area (within the so-called Uściwierz Lowering), the originally interior catchments were repeatedly integrated with the drainage network. The area was dissected by ditches and water flow directions were changed, so that the area was connected to the basins of the Wieprz or Bug River (Suchożebrska and Chabudziński 2007). It was found that multi-directional hydrologic transformations had taken place in Lake Sumin's catchment, which had belonged to the Wieprz River's basin at the beginning of the $20^{\text {th }}$ century. In the second half of the $20^{\text {th }}$ century the water from the catchment was carried to the basin of the Włodawka River, which is a tributary of the Bug River. In the first decade of the $21^{\text {st }}$ century the streamflow to the Włodawka River was cut off, thus Lake Sumin's catchment became closed. After hydrotechnical amelioration works, Uściwierz and Bikcze became flowthrough lakes, and Ciesacin and Nadrybie were converted into outflow lakes which fed the Piwonia River catchment. Great hydrographic changes are currently taking place in the vicinity of the Bogdanka Coal 
Mine (Michalczyk and Zarębski 1995; Michalczyk et al. 2007). As a result, the ground is subsiding and depression reservoirs permanently filled with water are being formed in vast basins (Fig. 1). One such example is the Nadrybie depression reservoir formed in 1997 (Chmiel et al. 2002). Nowadays it is impossible to determine the water divides between particular lake basins without detailed and precise land mapping. The directions of flow in catchments as well as in neighbouring areas are conditioned by the stage of water in ditches and channels, and they are also influenced by uncontrolled digging of the lake banks.

\section{Rainfall-water stage relationship}

The relationship between precipitation and water stages is the basic issue which characterises the formation process of lake water resources (the lake's retention capacity). The twenty-year observation period was marked by very uneven seasonal and spatial precipitation distribution. As the data for the whole period were unavailable, the precipitation amount registered by the Institute of Meteorology and Water Management in Włodawa was used for the analysis. After the excep- tionally dry 2003, with a precipitation of only $370 \mathrm{~mm}$, the water level of the lakes dropped to very low water stages for several years. It was only the very high precipitation of 2009, as much as $775 \mathrm{~mm}$, that caused a considerable increase in lake water resources (Fig. 4).

Effective precipitation, which causes a considerable increase in water stages, was determined for Lake Piaseczno by using the graphical method (Fig. 4). Total annual precipitation exceeding $530 \mathrm{~mm}$ resulted in a rise of lake retention capacity in the following year. Water level altitude then exceeded $169.70 \mathrm{~m}$ a.s.l.

A comparison between annual precipitation totals and average annual water stages clearly indicates that a lake's reaction time to the rise or drop in atmospheric inflow is approximately one year (Fig. 5).

From a multi-annual perspective (1991-2010) it was observed that the lowest average monthly precipitation was in January - $24 \mathrm{~mm}$ - whereas the highest precipitation was in July - $75 \mathrm{~mm}$ (Fig. 6). The lowest water stages in the 7 lakes covered by complete and continuous observations occurred mostly in November and October, and the highest ones in April and May (Fig. 6). Therefore, the lake inflow regime is a rain-and-snow regime, whereas the yearly replenish-

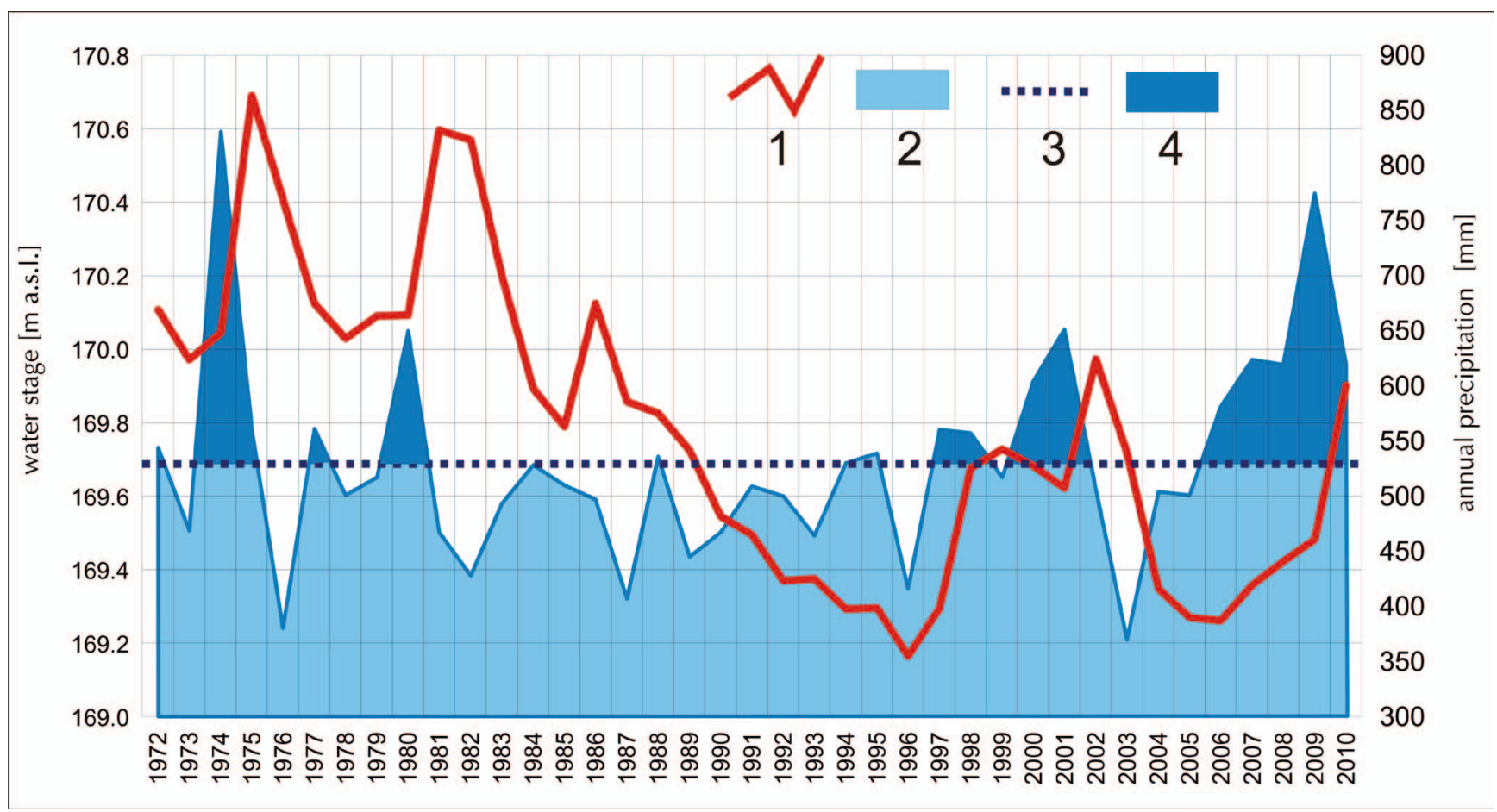

Fig. 4. Average annual water stages in Lake Piaseczno and annual rainfall totals (1972-2010). 1 - lake water stages, 2 - annual precipitation total, 3 - effective precipitation boundary, 4 - effective precipitation 


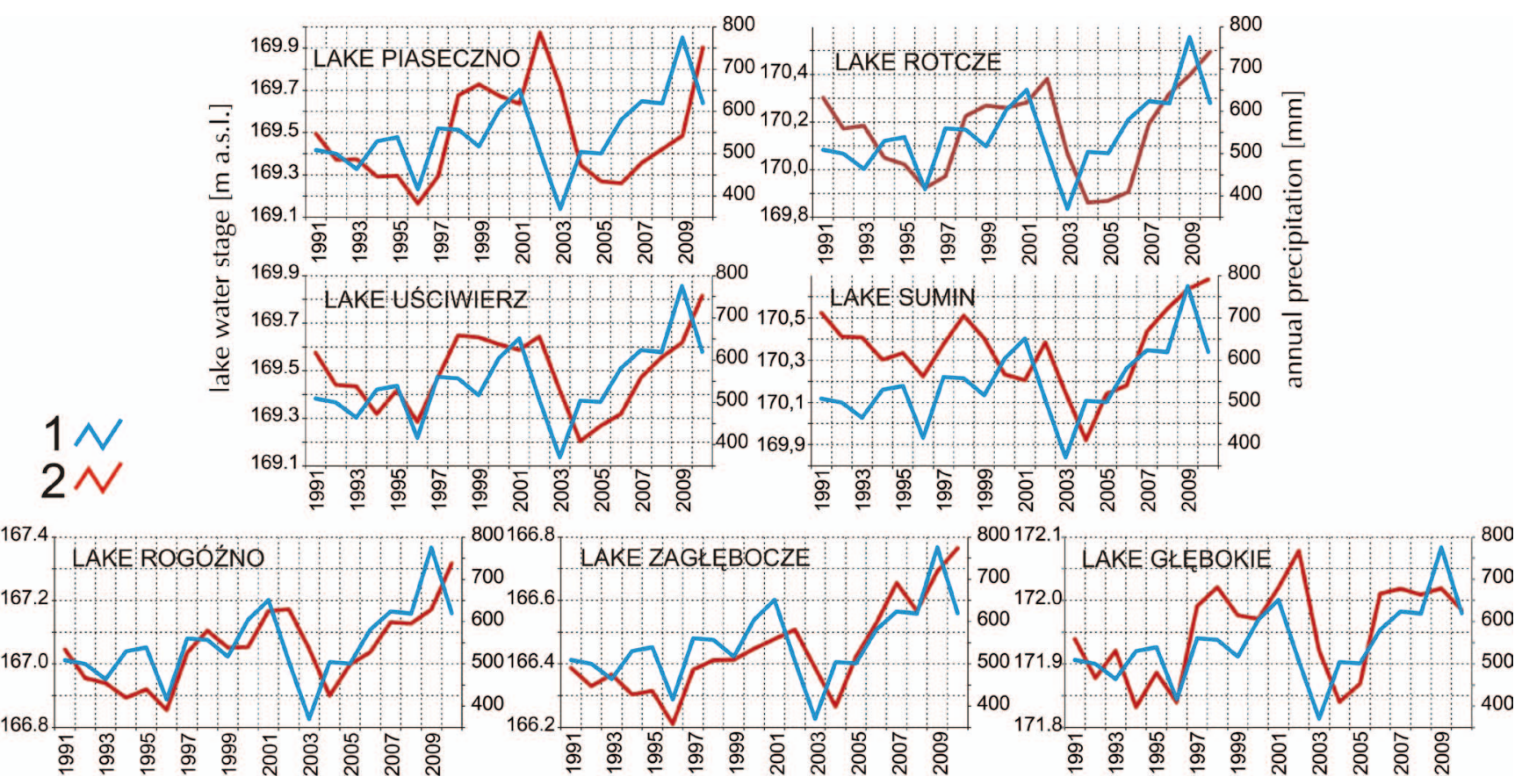

Fig. 5. Annual precipitation totals and average annual lake water stages. 1 - total precipitation, 2 - average lake stage

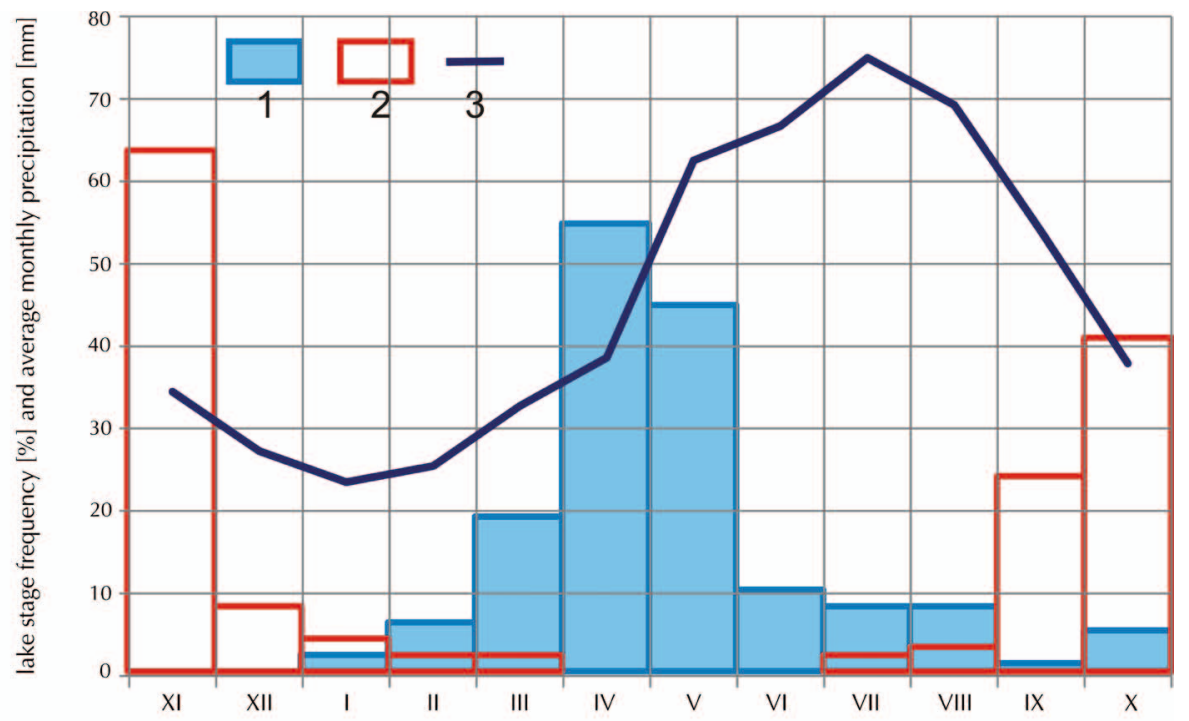

Fig. 6. Frequency of occurrence of high and low lake water stages against average monthly precipitation (1991-2010). 1 - maximum stage frequency, 2 - minimum stage frequency, 3 - average monthly precipitation

ment of water resources is linked to water abundance in the cold half of the year. The maximum annual water stages occurred sporadically in the summer months: after exceptionally heavy rainfall exceeding $150 \mathrm{~mm}$ monthly. The highest annual water stages were not registered in November or December, and the minimum water stages did not occur in April, May or June. It should be noted, though, that water stages in the majority of lakes are mostly determined by precipitation. The river water inflow to Uściwierz lakes is insignificant because they are located in small catchments situated near water divides.

The observation data analysis did not show synchronous relationships between average monthly water stages and the precipitation level (Fig. 7A). The reaction time of the lakes to the inflow was determined 

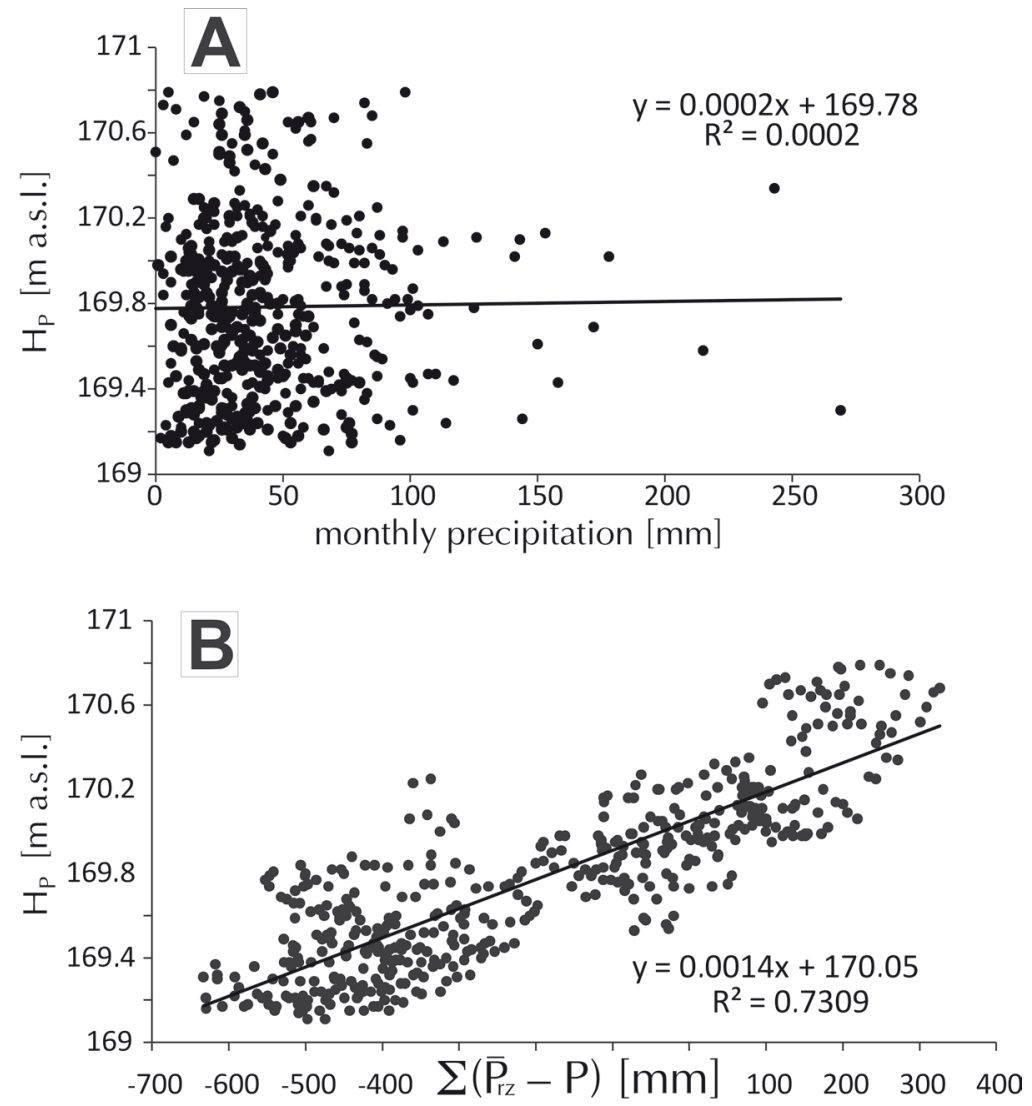

Fig. 7. Relationship between monthly precipitation totals and average water stages in Lake Piaseczno (A) and relationship between cumulative differences $\sum\left(\mathrm{P}_{\mathrm{rz}}-\bar{P}\right)$ and average monthly water stages in Lake Piaseczno (B)

based on the analysis of precipitation and water losses. Further statistical approximations revealed a dependence between the cumulative values: water level altitude and each month's precipitation reduced by the average value for the multi-annual period (Fig. 7B).

The relationship between a water stage in Lake Piaseczno and the cumulative differences of actual monthly precipitation values reduced by the average monthly value for the multi-annual period is shown in straight-line regression analysis (Fig. 7B):

$$
\mathrm{H}_{\mathrm{p}}=0.0014 \sum\left(\mathrm{P}_{\mathrm{rz}}-\bar{P}\right)+170.0484 ; \quad \mathrm{r}^{2}=0.7309
$$

where: $\mathrm{H}_{\mathrm{p}}$ - water level altitude of Lake Piaseczno (m a.s.l.), $\mathrm{P}_{\mathrm{rz}}^{\mathrm{p}}-\mathrm{monthly}$ total of the registered precipitation $(\mathrm{mm})$ and $\bar{P}$ - average monthly precipitation in the analysed multi-annual period ( $\mathrm{mm})$.

By way of iteration, a formula that can be applied to forecast lake water stages a half-year in advance was developed (Fig. 8):

$$
\mathrm{H}_{\mathrm{p}}=0.0014 \sum\left(\mathrm{P}_{\mathrm{rz}}-\bar{P}\right)+170.047 ; \quad \mathrm{r}^{2}=0.7219 .
$$

Astrophysical factors indirectly determined rainfall that guarantees an abundance of water in lakes. The search for the relationship between solar activity and water stages in Lake Piaseczno, the deepest one in the Lake District area, was continued with the use of the longest water stage series of observations carried out for the lake (Michalczyk and Turczyński 2001). The observation data updated for the following years confirm that the water stage fluctuation pattern is synchronised with solar activity in its $23^{\text {rd }}$ cycle and at the beginning of its $24^{\text {th }}$ cycle (Fig. 9). A relationship of this kind was also analysed in other regions of the world (Alexander et al. 2007; Mauas et al. 2011). Changes in the North Atlantic Oscillation, expressed as the NAO index, also occur as a consequence of solar activity changes. A relationship between the NAO index, which describes the winter climate and seasonal and multi-annual water stage fluctuations was documented for several lakes in the north-eastern part of Poland (Górniak and Piekarski 2002). 


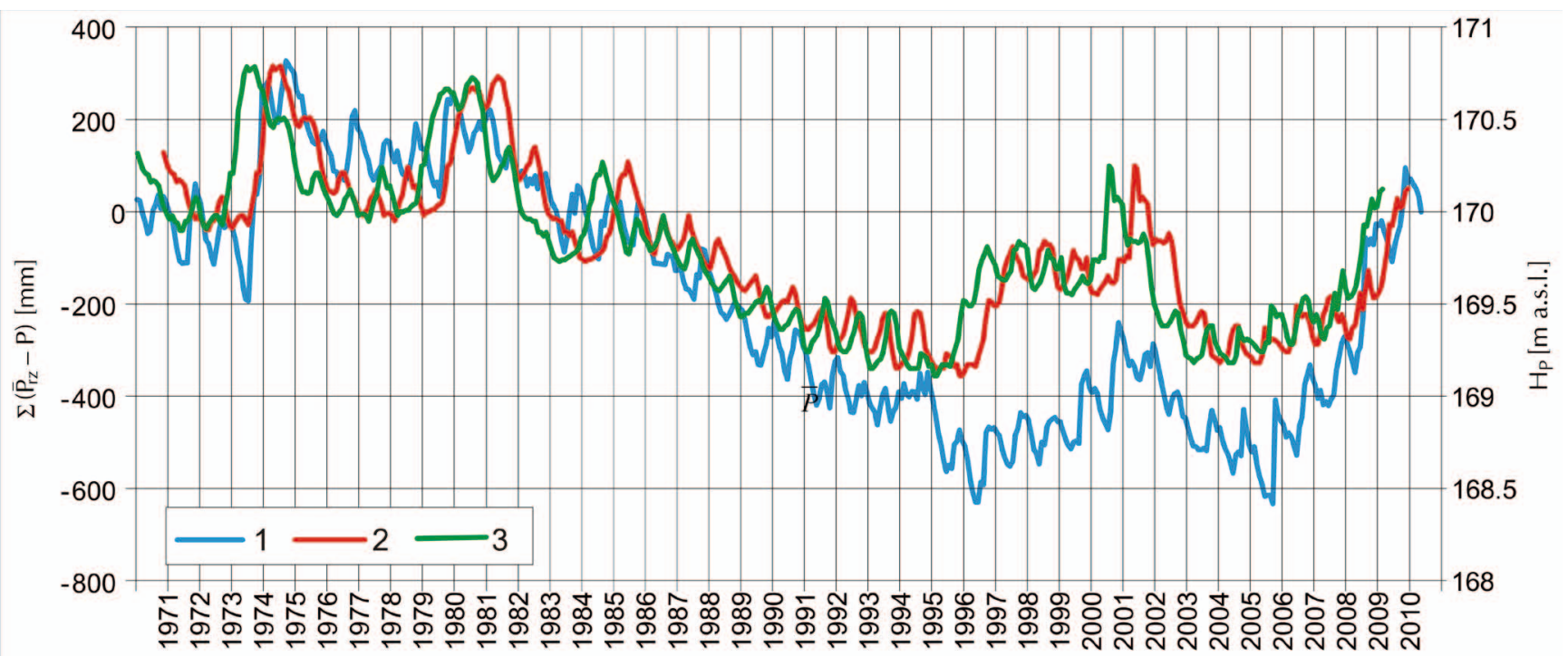

Fig. 8. Cumulative monthly precipitation values expressed as the total of differences $\Sigma\left(\mathrm{P}_{\mathrm{rz}}-\bar{P}\right)$, average monthly water stages in Lake Piaseczno $\left(\mathrm{H}_{\mathrm{p}}\right)$ and $\mathrm{Hp}$ forecast half a year in advance. $1-\Sigma\left(\mathrm{P}_{\mathrm{rz}}-\bar{P}\right)[\mathrm{mm}], 2-\mathrm{H}_{\mathrm{p}}\left[\mathrm{m}\right.$ a.s.l.] $3-\mathrm{H}_{\mathrm{p}}$ a half-year forecast of water stages

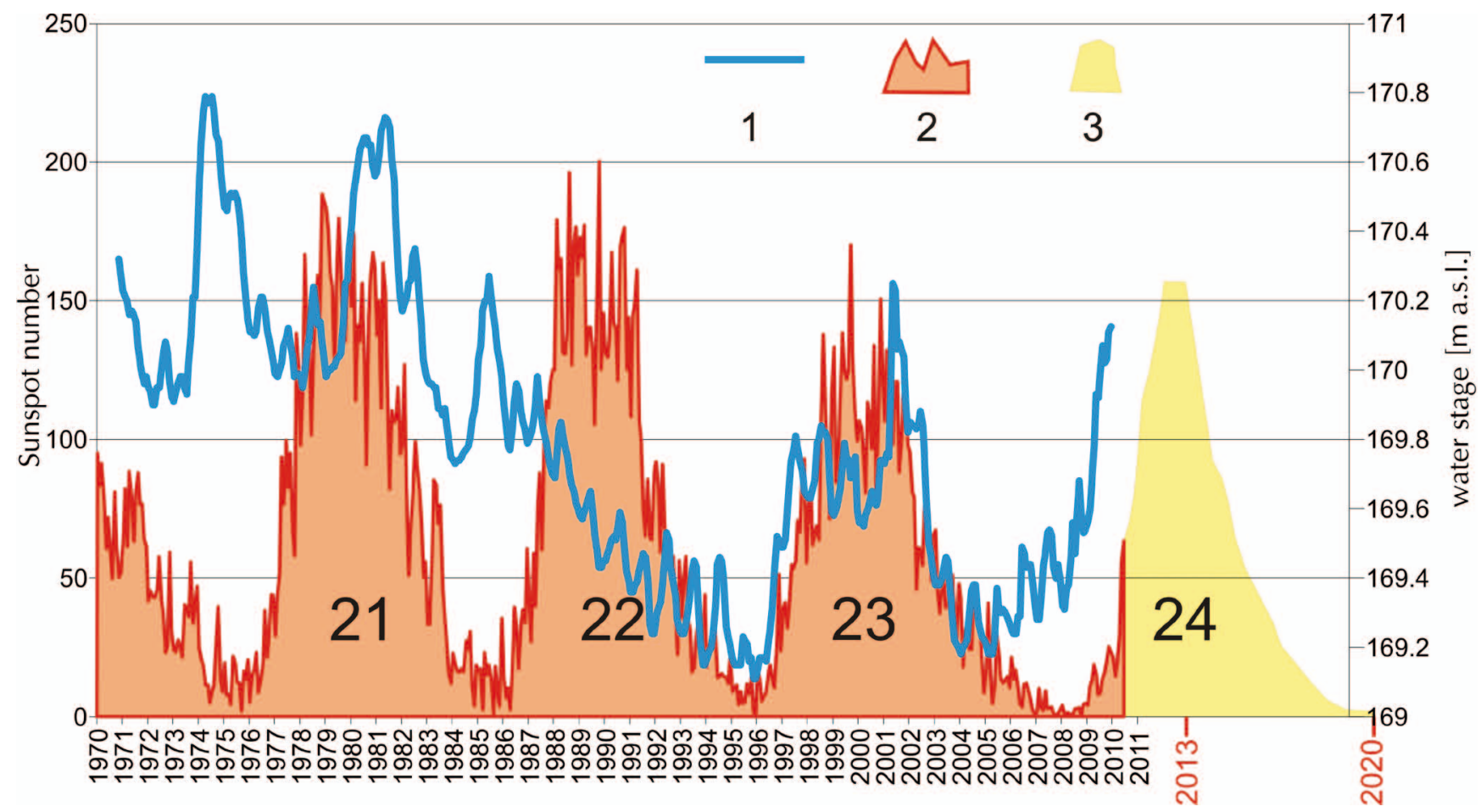

Fig. 9. Water stages in Lake Piaseczno in relation to solar activity. 1 - water stages in Lake Piaseczno [m a.s.l.], 2 - solar activity [sunspot number], 3 - forecast solar activity, 21-24 - solar cycle numbers 


\section{Conclusions}

Water stage changes result from both climatic fluctuations and human economic activities. In the Łęczna-Włodawa Lake District, the amplitude of water stage variations in natural lakes ranged from 43 to $110 \mathrm{~cm}$ in the years 1991-2010. Water stage changes, due to high inflow or its lack, took place with a several-month delay period.

In the years 1991-2010 monthly precipitation totals showed a slightly upward trend, whereas in the longer period (1971-2010) no such tendency was observed.

In 1991-2010 the lowest lake water stages occurred in two periods between the years 1994-1996, and slightly higher stages were recorded in the years 2004-2005. The maximum stages were registered in the last years of the observation period (2009-2010).

The water stages of Lake Piaseczno, considered to be a benchmark lake for the area throughout the whole observation period (1971-2010), changed cyclically. The high water stages of Lake Piaseczno in the years 1991-2010 were approximately $50 \mathrm{~cm}$ lower than the maximum values of the previous twenty years (1971-1990). Over the whole observation period, a clear downward trend for water stage changes was noted. Low water stages in the last 20 years caused a rise in the water level amplitude to $171 \mathrm{~cm}$.

In the years 1991-2010 the relationship between water resource dynamics of the Uściwierz lakes was disturbed. The disturbance might have been caused by mining or by a random, uncontrolled distribution of water over the dense network of drainage ditches.

\section{References}

Alexander W. J. R., Bailey F., Bredenkamp D. B, Van der Merwe A., Willemse N., 2007, Linkages between solar activity, climate predictability and water resource development, J. S. Afr. Instit. Civ. Eng. 49(2): 32-44.

Chmiel S., Michalczyk Z., Turczyński M., 2002, Hydrological changes of waters in reservoirs formed as a result of mining deformations. Limnol. Rev. 2: 57-62.
Górniak A, Piekarski K., 2002, Seasonal and Multiannual Changes of Water Levels in Lakes of Northeastern Poland, Pol. J. Environ. Stud. 11(4): 349-354.

Harasimiuk M., Michalczyk Z., Turczyński M., (eds), 1998, Jeziora łęczyńsko-włodawskie. Monografia przyrodnicza. (The Łęczna-Włodawa lakes. Environmental monograph), Biblioteka Monitoringu Środowiska, UMCS, PIOS, Lublin, p. 176 (in Polish).

Mauas P. J.D., Buccino A. P., Flamenco E., 2011, Long-term solar activity influences on South American rivers, J.Atmos. Sol.-Terr. Phy. 73(2-3): 377-382.

Michalczyk Z., Chmiel S., Turczyński M., 2003, Stosunki wodne w obszarze funkcjonalnym Poleskiego Parku Narodowego (Water conditions in the functional area of Polesie National Park), Acta Agrophys. Rozpr. Monogr. 91: 26-67 (in Polish).

Michalczyk Z., Turczyński M., 2001, Lake - levels and solar activity, Limnol. Rev. 1: 207-212.

Michalczyk Z., Zarębski K., 1995, Wymiana wód podziemnych w południowo-zachodniej części Pojezierza Łęczyńsko-Włodawskiego w rejonie KWK „Bogdanka” (Ground water interchange in the south-western part of the Łęczna-Włodawa Lake region in the Bogdanka Colliery), [in:] Mat. konf. VII Sympozjum „Współczesne problemy hydrogeologii” T VII, cz. 2, Wyd. AGH, Kraków-Krynica: 119-126. (in Polish).

Michalczyk, Z. Chmiel, S. Chmielewski, J. Turczyński, M., 2007, Hydrologiczne konsekwencje eksploatacji złoża węgla kamiennego w rejonie Bogdanki (LZW) (Hydrological consequences of hard coal mining in the area of Bogdanka (LCB)), Biul. PIG 422: 113-125 (in Polish, English summary).

Perez-Peraza J., Leyva-Contreras A., Valdes-Barrón M., Libin I., Yudakhin K., Jaani A., 2005, Influence of solar activity on hydrological processes, Hydrol. Earth Syst. Sci. Discuss. 2: 605-637, doi:10.5194/hessd-2-605-2005.

Suchożebrska M., Chabudziński Ł.,2007, Anthropogenic Transformations of the Hydrographical Network in Lake Catchment Areas of the Uściwierz Lowering (Łęczna-Włodawa Lake District), Limnol. Rev. 7(4): 225-231.

Wilgat T., Janiec B., Michalczyk Z., Turczyński M., 1997, Hydrological consequences of human action in the Łęczna-Włodawa Lake Region, Geogr. Pol. 68: 117-147.

Wilgat T.,1954 - Jeziora Łęczyńsko-Włodawskie (The Łęczna-Włodawa lakes), Ann. UMCS B 8: 37-122 (in Polish, English summary). 